\title{
Plastic Allometry in Coarse Root Biomass of Mature Hybrid Poplar Plantations
}

\author{
Julien Fortier $^{1} \cdot$ Benoit Truax $^{1} \cdot$ Daniel Gagnon $^{1,2} \cdot$ France Lambert $^{1}$ \\ Published online: 12 May 2015 \\ (C) The Author(s) 2015. This article is published with open access at Springerlink.com
}

\begin{abstract}
In this study, we sampled coarse root biomass of three poplar clones in four 13-year-old hybrid poplar (Populus spp.) plantations, with the objective of developing an allometric relationship between diameter at breast height (DBH) and coarse root biomass. A second objective was to test significance of site, clone and $\times$ site clone interaction effects on coarse root biomass, using analysis of covariance (ANCOVA), with $\mathrm{DBH}$ as a covariate. Across the four sites, the general allometric relationship between DBH and coarse root biomass was highly significant $\left(R^{2}=0.78, p<0.001\right)$. However, given the high significance of the site effect $(p<0.001)$ in the ANCOVA and the differences in data distribution between sites, two allometric relationships were developed based on the fertility class of sites (high and moderate). Environmentspecific allometric relationships developed for two site fertility classes had a better fit $\left(R^{2}=0.81-0.90, p<0.001\right)$. ANCOVA, with $\mathrm{DBH}$ as a covariate and site fertility class as a main effect, also showed that both of these variables significantly affected $(p<0.001)$ coarse root biomass allocation. Environmentspecific equations showed that higher coarse root biomass
\end{abstract}

Julien Fortier

fortier.ju@gmail.com

Benoit Truax

btruax@frfce.qc.ca

Daniel Gagnon

daniel.gagnon@uregina.ca

France Lambert

france.lambert@frfce.qc.ca

1 Fiducie de Recherche sur la Forêt des Cantons-de-l'Est / Eastern Townships Forest Research Trust, 1 rue Principale, Saint-Benoît-duLac, QC, Canada J0B 2M0

2 Department of Biology, University of Regina, 3737 Wascana Parkway, Regina, SK, Canada S4S 0A2 was allocated in harsher environments for a given DBH, probably to improve access to growth limiting soil nutrients or to build-up larger storage sites for amino acids and non-structural carbohydrates. Consequently, poplar coarse root biomass growth is both driven by ontogeny (size) and environment, reflecting the plasticity of the root system of mature poplars. Implications of using general vs. environment-specific equations in estimating stand-level root biomass and shoot to root ratios are discussed. Shoot to root ratios calculated using environment-specific equations were more strongly correlated to key environmental variables than ratios calculated using the general equation, with soil $\mathrm{NO}_{3}$ supply rate being the strongest predictor of the ratio $\left(R^{2}=0.90, p<0.001\right)$.

Keywords Plasticity - Belowground biomass equation - Site fertility $\cdot$ Large woody roots · Bioenergy $\cdot$ Carbon partitioning and allocation

\section{Introduction}

In many parts of the world, poplar (Populus spp.) plantations are not only established to meet the growing demand for bioenergy and wood production but also to increase environmental protection [1]. Planted poplars cover approximately 8.6 million ha worldwide, making poplar plantations and agroforestry systems a very important land use at the global scale [1]. Land area under poplar cultivation is also expected to increase in the future because many countries have vast zones of marginal agricultural land that could be converted to bioenergy plantations to satisfy national energy demands $[2,3]$. For example, it was estimated that $8 \%$ of the energy demand of Romania could be met with poplar biomass produced on the 1 million ha of recently abandoned arable land [4]. 
In the context of global change, afforested poplar plantations for bioenergy are effective to offset carbon (C) emissions because they can contribute to fossil fuel displacement and $\mathrm{C}$ storage on former agricultural land [5-8]. Therefore, increasing our knowledge about $\mathrm{C}$ cycling and storage in poplar plantations is important to assess the $\mathrm{C}$ balance of this expanding type of land use. There is growing evidence that the establishment of short rotation coppices and fast-growing plantations of broadleaved species on agricultural land may not increase soil $\mathrm{C}$ stocks on a general basis [9-11], with considerable uncertainties regarding the sustainability of soil organic $\mathrm{C}$ enrichment in bioenergy woody crops [12]. However, many of these systems may increase, on the shortterm, belowground $\mathrm{C}$ storage through root biomass growth [13]. This belowground biomass has a large contribution to the positive $\mathrm{C}$ balance achieved by short rotation coppices over multiple rotations [14]. Also, in terms of stability, C stocks in large roots have slow decay rates compared to other forest residues [15].

Important improvements of belowground $\mathrm{C}$ estimates in forests and plantations could be made by developing allometric relationships between tree diameter and coarse root biomass of different species across gradients of environmental conditions [16]. This is because large roots generally account for $70 \%$ or more of total root biomass [17]. From an economic perspective, there is also a need for a better quantification of belowground biomass. The growing demand for bioenergy in many parts of the world has stimulated the exploitation of new sources of feedstock, such as stump and coarse root biomass that can be extracted following harvest $[18,19]$.

Biomass growth and partitioning is a key feature of most bioenergy crop models, with allometry being a common empirical approach to describe the distribution of biomass into different structural components [20,21]. Yet, the potential effects of environmental conditions on coarse root biomass growth and allometry have received little attention over the years. In poplar plantations, a few studies have developed allometric relationships between diameter at breast height (DBH) and coarse root biomass in different plantation environments [22, 23, 19, 24, 25]. These relationships have also been developed in natural poplar stands [26, 27]. However, all of these field studies reported only a single allometric relationship between DBH and coarse root biomass, with no evidence of coarse root biomass plasticity in relation to environmental factors. This is surprising given that site quality can affect allometric relationships between stem diameter and aboveground compartments in short rotation coppices of willows $[28,29]$. In more widely spaced and older poplar plantations, growth environment likely influenced the relationship between DBH and different aboveground woody biomass components [30]. Change of allometry between coarse roots and shoots has also been reported in lodgepole pine (Pinus contorta) stands along a stress gradient in forests of the sub- boreal zone [31]. Furthermore, poplar genotype could influence patterns of biomass allocation to coarse roots since significant genotype effects were observed on the relationships between DBH and different aboveground biomass components of even-aged plantations [32].

Most evidence regarding the plastic response of poplar root systems in field experiments are related to fine root production dynamics [33]. For example, in a recently established poplar plantation for bioenergy, drought conditions in the spring stimulated fine root production, while leading to a decrease in gross primary production [34]. In a field study where environmental conditions had been manipulated, high soil $\mathrm{N}$ and elevated atmospheric $\mathrm{CO}_{2}$ were found to increase fine root production and mortality, with soil $\mathrm{N}$ greatly affecting $\mathrm{C}$ partitioning between leaves and fine roots [35].

Changes in poplar shoot and root allometry in response to environmental conditions have been mainly reported in greenhouse experiments involving young plant material. As shown by Liu \& Dickmann [36], increasing $\mathrm{N}$ availability in soil did not affect total root biomass production, but greatly increased shoot biomass of 37-day-old poplars. Similarly, 28 days of exposure to intermediate and luxuriant $\mathrm{N}$ concentrations resulted in significant changes in poplar architecture, with stem biomass being positively affected by $\mathrm{N}$ treatments, while total root biomass remained unaffected [37]. This short-term plastic response resulted in different allometric relationships between stem and root biomass under the different $\mathrm{N}$ treatments, suggesting that poplars can initiate rapid tree architecture changes when $\mathrm{N}$ is available, in order to increase $\mathrm{C}$ fixation capacity, and eventually favour stem growth over root growth [37]. These allometric trends are consistent with the "optimal partitioning theory," which suggests that plants invest resources for improving their access to the currently limiting factor [31, 38]. However, is this plastic response of tree architecture to site fertility still perceptible for mature poplar trees growing in contrasted plantation environments? This question is of particular interest given that tree plasticity in response to limited resources may decline with increasing age and/or time of exposure to the limiting resources [39, 40].

Coarse roots are also multifunctional tree components providing key functions such as transport (nutrients, photosyntate, water), storage (sugars and nutrients) and biomechanical stabilisation, as well as being the framework upon which fine root develop and connect [41-43]. The relative importance of such functions will likely vary with tree development and growth environment. Consequently, as the aboveground components grow taller, wider and heavier, the stabilisation function of coarse roots in fast-growing tree plantations may become of overriding importance in the biomass allocation strategy to roots, potentially obscuring the effect of fertilisation or site fertility on coarse root allometry [41]. Consequently, a plastic response of coarse root biomass will likely depend on the particular requirement for these functions in a particular 
environment at a specific time in tree development. Trees are large, modular and long lived, and conflicting and lagged signals travel through the vascular system from different structures over time [44]. This further complicates our understanding of tree $\mathrm{C}$ balance and allocation under natural conditions.

In this study, we collected coarse root biomass data of three poplar genotypes in four 13-year-old hybrid poplar plantations located along a gradient of elevation and soil fertility. Two of the plantations have higher site fertility and high aboveground yields, while the two others have moderate site fertility and moderate yields. The first objective of this study was to develop a general allometric relationship between $\mathrm{DBH}$ and coarse root biomass for mature poplar plantations. The second objective was to use this allometric relationship to estimate coarse root biomass of the three hybrid poplar clones across the four sites, but also to estimate shoot to root ratio using aboveground biomass data of Truax et al. [32], which were collected in the same year. We also verified the plastic allometry hypothesis [45] for coarse root biomass growth in contrasted plantation environments by testing the significance of the site effect and $\mathrm{DBH}$, as a continuous covariate, on coarse root allocation using analysis of covariance (ANCOVA). The genotype and the site $\times$ genotype interaction effects were also tested.

\section{Materials and Methods}

\section{Site Description and Experimental Design}

The study sites are located on privately owned abandoned farmland in the Eastern Townships region of southern Québec, Canada. Four different plantation sites (Bedford, Brompton, Melbourne and Ste-Catherine) were chosen along a regional gradient of elevation (climate) and soil characteristics, with higher mean annual temperature and longer growing season being found on lower elevation sites of the region [46].

The Bedford and Brompton sites have a high site fertility and high aboveground woody biomass yields (11.4 and $9.6 \mathrm{t} /$ ha/year after 13 years), while the Melbourne and SteCatherine sites have moderate site fertility and moderate yields (5.2 and $6.1 \mathrm{t} / \mathrm{ha} /$ year after 13 years) [32] (Table 1). The four study sites are located within a radius of $50 \mathrm{~km}$, with all plantations sites being nearly flat, with slopes always under $5 \%$. The geology of the study area is complex, but the bedrock is almost completely covered with glacio-fluvial and glacial till deposits [46]. The region is characterised by a continental subhumid moderate climate and mean annual precipitation ranges from 900 to $1,100 \mathrm{~mm}$ [46].

In the year of the study (2012), all plantations were in their 13th growing season. Pre-plantation site preparation included ploughing and disking each site in fall 1999. In the spring of 2000, bare-root planting stock with 2-m-long stems were planted manually with shovels at 30 to $40 \mathrm{~cm}$ depth at a spacing of $3 \times 4 \mathrm{~m}$, for a tree density of 833 stems/ha. Planting stock (1-0) was provided by the Berthierville nursery of the Ministère des Ressources naturelles - Forêt (MRNF) of Québec. Competing vegetation was eliminated with glyphosate herbicide application over the entire plantation area in June 2000, and between plantation rows only, in June 2001.

The initial experimental design contained eight plantation sites, with three blocks per site, and nine poplar clones. However, for the purposes of this study, only three clones (with contrasted parentages) and four sites were used. These three unrelated hybrid poplar clones were: Populus deltoides $\times$ nigra (DxN-3570, also named $P . \times$ canadensis), P. canadensis $\times$ maximowiczii (DNxM-915508) and P. maximowiczii $\times$ balsamifera (MxB-915311). These clones had been selected for superior disease resistance/tolerance and growth characteristics in MRNF genetic selection trials in southern Québec [47]. A randomized block design was used at each of the four sites, with three blocks (nested in sites) and three plots per block (one plot per hybrid poplar clone), for a total of 36 experimental plots (4 sites $\times 3$ blocks $\times 3$ clones, $n=36$ ). Plots are $12 \mathrm{~m}$ wide and $12 \mathrm{~m}$ long $\left(144 \mathrm{~m}^{2}\right)$. Each plot initially contained 12 trees from a single clone (3 rows, 4 trees per row). Trees are spaced $3 \mathrm{~m}$ apart on the row, and the rows are $4 \mathrm{~m}$ apart. At all sites, one guard row of poplar trees was planted around the entire perimeter of the plantation, in order to reduce edge effects that could affect nutrient and water uptake, as well as exposure to open field light and wind conditions.

\section{Soil Characteristics and Nutrient Supply Rates}

In each plot, a composite soil sample was collected to a depth of $20 \mathrm{~cm}$. Soil samples were air dried and sieved $(2 \mathrm{~mm})$. Soil $\mathrm{pH}$, clay, silt and sand content, percent organic matter, cation exchange capacity (CEC) and base saturation were determined by the Agridirect Inc. soil analysis lab in Longueuil (Québec). Methods used are those recommended by the Conseil des productions végétales du Québec [48]. The determination of soil $\mathrm{pH}$ was made using a 1:1 ratio of distilled water to soil. For particle size analyses, the Bouyoucos [49] method was used. Percent organic matter was determined by weight loss after ignition at $550{ }^{\circ} \mathrm{C}$ for $4 \mathrm{~h}$. Cation exchange capacity and base saturation were calculated following the recommendations of the Centre de référence en agriculture et agroalimentaire du Québec [50], after $\mathrm{Ca}, \mathrm{K}$ and $\mathrm{Mg}$ extraction with the Mehlich III method [51] and concentration determination using ICP emission spectroscopy [52]. Soil characteristics are presented in Table 1.

Nutrient supply rates (availability) in the entire experimental design was determined using Plant Root Simulator (PRS ${ }^{\mathrm{TM}}$-Probes) technology from Western Ag Innovations Inc., Saskatoon, Canada. The PRS-probes consist of an ion exchange membrane encapsulated in a thin plastic probe, 
Table 1 Site and soil characteristics $(0-20 \mathrm{~cm})$ of the four hybrid poplar plantation sites

\begin{tabular}{lllllllll}
\hline Sites & $\begin{array}{l}\text { Site } \\
\text { fertility }\end{array}$ & $\begin{array}{l}\text { Biomass yield } \\
(\mathrm{t} / \text { ha/year })\end{array}$ & $\begin{array}{l}\text { Elevation } \\
(\mathrm{m})\end{array}$ & $\begin{array}{l}\text { Clay-Silt- } \\
\text { Sand (\%) }\end{array}$ & $\mathrm{pH}$ & $\begin{array}{l}\text { Organic } \\
\text { matter (\%) }\end{array}$ & $\begin{array}{l}\text { CEC } \\
(\mathrm{meq} / 100 \mathrm{~g})\end{array}$ \\
\hline Bedford & High & 11.4 & 80 & $22-22-56$ & 5.64 & 4.50 & 13.8 & $\begin{array}{l}\text { Base saturation } \\
(\%)\end{array}$ \\
Brompton & High & 9.6 & 170 & $24-49-27$ & 5.68 & 5.00 & 14.3 & 45.2 \\
Melbourne & Moderate & 5.2 & 330 & $14-37-49$ & 5.47 & 6.81 & 12.7 & 26.2 \\
Ste-Catherine & Moderate & 6.1 & 230 & $13-39-48$ & 5.20 & 6.23 & 12.2 & 0.5 \\
SE & - & - & - & - & 0.07 & 0.22 & 0.0 & 2.7 \\
$p<$ & - & - & - & - & 0.001 & 0.001 & 0.06 & 0.001 \\
\hline
\end{tabular}

Aboveground woody biomass yield data are from Truax et al. [32]

which is inserted into the ground with little disturbance of soil structure. Nutrient availability predicted with this method is generally significantly correlated with conventional soil extraction methods over a wide range of soil types [53], and which has also been corroborated in poplar riparian agroforestry systems of the study region [54, 55]. In August 2012, four pairs of probes (an anion and a cation probe in each pair) were buried in the A horizon of each plot for a 35-day period. After probes were removed from the soil, they were washed in the field with distilled water, and returned to Western Ag Labs for analysis $\left(\mathrm{NO}_{3}, \mathrm{NH}_{4}, \mathrm{P}, \mathrm{K}, \mathrm{Ca}\right.$ and $\left.\mathrm{Mg}\right)$. Composite samples were made in each plot by combining the four pairs of probes. Nutrient supply rates at each site are reported as microgram of nutrient per $10 \mathrm{~cm}^{2}$ per 35 days (Table 2).

\section{Coarse Root Biomass Sampling}

In July 2012, coarse root biomass was sampled in the soil occupied by one representative tree of each plot $(n=36)$, in a plot section where there was full stocking. A large rectangular pit was excavated using a small mechanical excavator. The size of the excavated pits was $1.5 \mathrm{~m} \times 2 \mathrm{~m} \times 0.60 \mathrm{~m}$ depth, which corresponds to $25 \%$ of the surface area occupied by a single tree for a plantation density of 833 stems/ha (Fig. 1). This approach was chosen because large monoliths are required for representative coarse root sampling [56]. The position of the quadrant sampled was randomly selected. To

Table 2 Nutrient supply rate $\left(\mu \mathrm{g} / 10 \mathrm{~cm}^{2} / 35\right.$ days $)$ in soil measured during 35 days at the end of summer 2012 at the four hybrid poplar plantation sites

\begin{tabular}{lllllll}
\hline Sites & $\mathrm{NO}_{3}$ & $\mathrm{NH}_{4}$ & $\mathrm{P}$ & $\mathrm{Ca}$ & $\mathrm{K}$ & $\mathrm{Mg}$ \\
\hline Bedford & 150.7 & 4.99 & 1.43 & 2389 & 75.7 & 249.6 \\
Brompton & 35.9 & 5.58 & 3.15 & 1450 & 62.0 & 227.1 \\
Melbourne & 3.8 & 5.09 & 0.70 & 542 & 94.0 & 85.3 \\
Ste-Catherine & 3.3 & 15.46 & 1.91 & 281 & 159.7 & 197.4 \\
SE & 9.4 & 5.09 & 0.75 & 142 & 17.1 & 14.8 \\
$p<$ & 0.001 & $\mathrm{NS}$ & $\mathrm{NS}$ & 0.001 & 0.01 & 0.001 \\
\hline
\end{tabular}

facilitate the work of the excavator operator, the sampling area was delineated with white paint sprayed on the ground. Sampled tree DBH was measured prior to excavation. Once a pit was excavated, the tap root was cleaned and its length, large end and small end diameters were measured in the field with a caliper. All sampled trees had a tap root, which probably reflects the type of plant material that was used to establish the plantations and the planting depth of this material (bareroot plants planted at a $30-40 \mathrm{~cm}$ of depth), as planting depth and plant material influence root system architecture in hybrid poplars [57]. Tap root formation have also been observed in a Euramerican clone grown in plantation after 5 years [58]. Tap root volume was calculated using the Smalian formula [59]. Tap root biomass was obtained by multiplying its volume by the mean density of hybrid poplar coarse roots $\left(0.313 \mathrm{~g} / \mathrm{cm}^{3}\right)$ [19]. All coarse roots (diameter $>2 \mathrm{~mm}$ ) in excavated pits were hand cut with a saw, removed, cleaned and air dried for 2 months. For each plot, the entire air dried sample of coarse roots was then weighed and a subsample was taken to determine oven dry weight and water content of the air dried samples. This procedure was preferred to the preparation of subsamples in the field on fresh root biomass, which was dirty and required water cleaning prior to subsampling for water content determination. For each sampled tree, total coarse root biomass (oven dry weight) was calculated as follows:

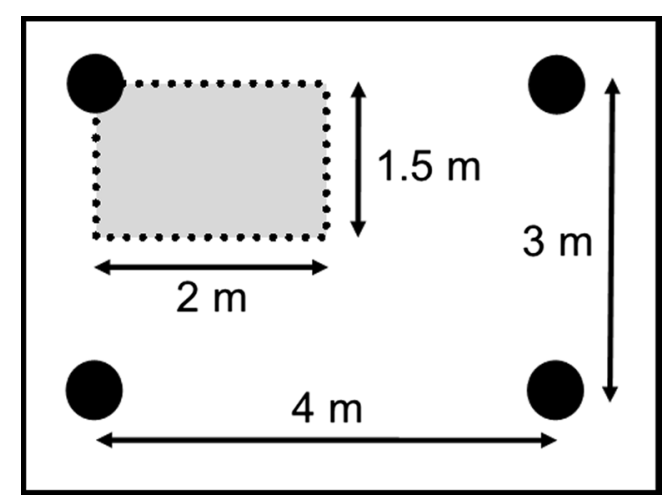

Fig. 1 Sampling design for coarse root biomass. The black circles represent poplars and the grey rectangle is the sampling area. This area is $25 \%$ of the area occupied by each poplar, as defined by the spacing of planted trees 
(Biomass collected from pits $\times 4$ ) + Taproot biomass $=$ Total coarse root biomass.

\section{Regression Procedures for Allometric Relationships}

With coarse root biomass data obtained from the 36 sampled trees, a regression model for coarse root biomass versus DBH was developed, with DBH being the predictor variable $(x)$ and coarse root biomass being the response variable $(Y)$. Common simple models describing allometric relationships in trees were tested, including linear, polynomial, exponential and power functions [60]. Residuals of the different models were plotted and compared to a normal distribution in order to determine the goodness-of-fit according to the Shapiro-Wilk $W$ test, the best omnibus test for testing normality of a distribution for small sample sizes $(n<50)$ [61]. Regression model selection was based on (1) the significance of model parameters, (2) the fit $\left(R^{2}\right)$ of the regression and (3) the goodness of fit $(W)$ or normality in residuals distribution. Therefore, when the fit of two different models with significant parameters was comparable, the model with the highest normality in the distribution of residuals was chosen. For nonlinear models, data were linearized prior to these analyses.

After data exploration and model fitting, one data point was removed from the data set of the Melbourne site $(\mathrm{DBH}=$ $14.0 \mathrm{~cm}$, coarse root biomass $=20.7 \mathrm{~kg}$ ) because the coarse root biomass measured was disproportionally high for the DBH value. The examination of a residual plot and an outlier boxplot also suggested that this data point was an outlier. This outlier was most likely related to the poor drainage of the soil at this particular location in the plantation, with the bottom of the pit filling up with water during the excavation; a situation that was not representative of the good drainage conditions observed in all of the other plots. As argued by Nikklas [62], outliers in allometric studies may be the result of unusual environmental circumstances, which is reflected by form or function compromises for a given organism within the context of these particular circumstances.

After developing a general allometric relationship between DBH and coarse root biomass using data from the four plantation sites, site, clone and site $\times$ clone interaction effects were tested on the relationship between DBH and coarse root biomass using analysis of covariance (ANCOVA). Data were log (ln) transformed prior to analysis. This ANCOVA tested $\mathrm{DBH}$, as a continuous covariate, and site, clone and site $\times$ clone interaction, as nominal effects on coarse root biomass. The site effect was highly significant $(p<0.001)$, while the clone effect and the site $\times$ clone interaction effect were nonsignificant ( $p=0.36$ and $p=0.95$, respectively). After plot examination of DBH to coarse root biomass data distributions at the four study sites, we observed that there was a considerable overlap between data from the Brompton and Bedford sites, but also between the Ste-Catherine and Melbourne sites.
Consequently, the data from the two high fertility sites (Bedford and Brompton) were combined, as were the data from the two moderate fertility sites (Melbourne and SteCatherine), creating two distributions, based on the site fertility class of sites (high vs moderate). These site fertility classes were consistent with soil characteristics, local climate in terms of plantation elevation and aboveground woody biomass yield at each site (Tables 1 and 2). Consequently, in this study, the term site fertility is used in its broad sense, as it refers not only to favourable soil conditions, but also to more favourable climatic conditions in terms of elevation or climate, given the temperature dependency of processes important for plant growth, such as $\mathrm{N}$-mineralisation in soil and ion uptake by roots [63]. Important covariation between elevation (climate) and different soil fertility indicators have been reported in poplar plantations of the region [64]. An ANCOVA was then used to test the significance of the site fertility class (high vs moderate), as a main effect, and DBH, as a continuous covariate, on coarse root biomass, using log transformed data. Given that the site fertility class effect and the continuous covariate (DBH) were highly significant $(p<0.001)$ an allometric relationship was developed for each of the two site fertility classes using the procedure aforementioned. Thus, an environment-specific model was developed for each of the two site fertility classes (high and moderate).

\section{Coarse Root Biomass and Shoot to Root Ratio Calculations}

Allometric relationships developed were then used to calculate coarse root biomass, from DBH measurements, for each living tree in the entire experimental design (all trees in the 36 sampled plots). The DBH measurements were taken from late October to early November 2012, at the end of the 13th growing season. In each plot, coarse root biomass calculated for each tree was cumulated, and then scaled up to a one hectare area. Mean coarse root biomass per tree data were obtained by dividing total plot coarse root biomass by the number of living trees in the plot. To explore the implications of using the general allometric relationship versus environment-specific allometric relationships developed for the two site fertility classes, we calculated coarse root biomass in the four hybrid poplar plantations using both modelling approaches. The model developed for moderate site fertility was used to calculate coarse root biomass for the Melbourne and Ste-Catherine sites, while the model developed for high site fertility was used in calculations for the Bedford and Brompton sites.

Shoot to root ratios of 13-year-old poplar plantations were calculated at the plot level by dividing total aboveground woody biomass (data from Truax et al. [32]) by total coarse biomass data calculated with general and environmentspecific allometric relationships developed in this study. Our 
shoot to root ratios did not take into account fine root biomass nor coarse root biomass that would have been found below $60 \mathrm{~cm}$ depth, although some coarse roots were observed below this depth in most excavated pits. Therefore, it is likely that we have slightly underestimated coarse root biomass, and similarly slightly overestimated shoot to root ratio.

\section{Statistical Analysis}

Soil characteristics, calculated coarse root biomass data at the plot level and shoot to root ratios were analysed using a twoway ANOVA in a fixed factorial design. ANOVA tables were constructed in accordance with Petersen (1985), where degrees of freedom, sum of squares, mean squares and $F$ values were computed. When a main effect (site and clone) or the interaction effect (site $\times$ clone) was declared statistically significant, the standard error of the mean (SE) was used to evaluate differences between means for three levels of significance $\left({ }^{*} p<0.05,{ }^{* *} p<0.01\right.$ and $\left.{ }^{* * *} p<0.001\right)$. All of the ANOVAs were run with the complete set of data (36 experimental plots). Pairwise correlations were used to identify which of the following environmental factors were significantly correlated with shoot to root ratios: site elevation; soil pH, CEC and base saturation; soil organic matter, clay, silt and sand content, and soil supply rate of $\mathrm{NO}_{3}, \mathrm{NH}_{4}, \mathrm{P}, \mathrm{Ca}, \mathrm{K}$ and $\mathrm{Mg}$. Thereafter, regressions were developed between key environmental variables and shoot to root ratios. All statistical analyses were done using JMP 11 from SAS Institute (Cary, NC).

\section{Results}

\section{Site Characteristics and Soil Nutrient Supply Rates}

Based on site characteristics and yields, Bedford and Brompton were categorised as high fertility sites for poplar culture in this study (Table 1). Both of these sites are located at low elevation and shared similar soil characteristics in terms of clay content, $\mathrm{pH}$, percent organic matter, $\mathrm{CEC}$ and base saturation. The Melbourne and Ste-Catherine site characteristics contrast sharply with those observed at Bedford and Brompton: higher elevation, lower clay content, lower soil $\mathrm{pH}$, higher percent organic matter, lower CEC and lower base saturation (Table 1). Compared to the two moderate fertility sites (Melbourne and Ste-Catherine), much higher $\mathrm{NO}_{3}$ and Ca supply rates were also observed in late summer 2012, at the two high fertility sites (Bedford and Brompton). At Bedford and Brompton, $\mathrm{NO}_{3}$ supply rate, respectively, reached 150.7 and $35.9 \mu \mathrm{g} / 10 \mathrm{~cm}^{2} / 35$ days, while the supply rate of $\mathrm{NO}_{3}$ only reached 3.8 and $3.3 \mu \mathrm{g} / 10 \mathrm{~cm}^{2} / 35$ days at the Melbourne and Ste-Catherine sites respectively (Table 2). Meanwhile, Ca supply rate reached 2,389 and $1,450 \mu \mathrm{g} / 10 \mathrm{~cm}^{2} / 35$ days at Bedford and Brompton, respectively, while it only reached
542 and $281 \mu \mathrm{g} / 10 \mathrm{~cm}^{2} / 35$ days at Melbourne and SteCatherine, respectively (Table 2).

\section{Allometric Relationships for Coarse Root Biomass}

The selected general model describing the relationship between DBH (in centimetres) and coarse root biomass (in kilogrammes per tree) of hybrid poplars across the four plantation sites was in the form of a power function $\left(Y=\beta x^{\alpha}\right.$; Table 3), with parameter $\beta$ being the allometric constant and parameter $\alpha$ the scaling exponent [62]. Power functions have been widely used to describe allometric relationship between tree diameter and biomass components for a wide range of tree species and taxa $[65,66]$. This model and the estimated parameters were all highly significant $(p<0.001)$ and the model had a reasonably good fit $\left(R^{2}=0.78\right.$; Fig. 2, Table 3$)$. Allometric relationships developed with the same variables, but for the two site fertility classes, were also highly significant, as was the case for their estimated parameters (Table 3). However, the fit of these environment-specific models, both in the form of power functions, was higher $\left(R^{2}=0.81-0.90\right)$ than the fit of the general model (Table 3). These relationships suggest that for a given $\mathrm{DBH}$, a higher coarse root biomass was allocated by 13-year-old hybrid poplars on moderate fertility sites, compared to what was observed on high fertility sites (Fig. 3). This trend in root biomass allocation pattern also increased as hybrid poplar DBH increased, a consequence of the larger scaling exponent for the relationship developed with data from moderate soil fertility sites. The ANCOVA testing the significance of the site fertility class (high vs moderate), as a main effect, and DBH, as a continuous covariate, on coarse root biomass (using log transformed data) showed that the site fertility class effect was highly significant $(p<0.001)$, as was the case for DBH. However, the clone (genotype) and site $\times$ clone interaction effects were non-significant (see "Materials and methods" section for additional details). Moreover, the positive linear relationships between mean aboveground woody biomass per tree and mean coarse root biomass per tree, calculated at the plot level, showed that coarse root biomass increases linearly with increasing aboveground biomass, with the rate of increase (slope) being higher on moderate soil fertility sites, compared to what was observed on high soil fertility sites (Fig. 4).

\section{Coarse Root Biomass and Shoot to Root Ratios}

A significant site $\times$ clone interaction was observed on both coarse root biomass and shoot to root ratio estimates (Table 4), a trend reflecting observations made on aboveground woody biomass [32]. Based on data calculated with environment-specific allometric relationships, this interaction suggests that a small variation in coarse root biomass is observed for $P$. maximowiczii hybrids across the four sites, while 
Table 3 Allometric relationships between diameter at breast height (DBH, in centimetres), as the predictor variable $(x)$, and coarse root biomass (in kilogrammes per tree), as the response variable $(Y)$

\begin{tabular}{llllllll}
\hline Model name & $\begin{array}{l}\text { Trees sampled } \\
(\mathrm{n})\end{array}$ & $\begin{array}{l}\text { DBH range } \\
(\mathrm{cm})\end{array}$ & Model & $R^{2}$ & $F$ ratio & $W$ & $p<W$ \\
\hline General & 35 & $10.2-37.6$ & $Y=0.1083 x^{1.6506}$ & 0.78 & 114 & 0.97 & 0.38 \\
Moderate site fertility & 17 & $10.2-27$ & $Y=0.0238 x^{2.2246}$ & 0.90 & 136 & 0.91 & 0.10 \\
High site fertility & 18 & $20.1-37.6$ & $Y=0.0344 x^{1.9608}$ & 0.81 & 67 & 0.95 & 0.49 \\
\hline
\end{tabular}

The general model combines data from the four sites, the moderate site fertility model combines data from the Melbourne and Ste-Catherine sites, while the high site fertility model combines data from the Bedford and Brompton sites. All models and model parameters are significant at $p<0.001$. For each model, goodness of fit expressed by the Shapiro-Wilk statistic $(W)$ is presented with its associated $p$ value more than a threefold variation in coarse root biomass was observed for the DxN hybrid across sites. Coarse root biomass ranged from 12.4 to $18.5 \mathrm{t} / \mathrm{ha}$ at Bedford, 12.4 to $13.2 \mathrm{t} / \mathrm{ha}$ at Brompton, 5.2 to $18.1 \mathrm{t} / \mathrm{ha}$ at Melbourne and 10.4 to 16.1 at Ste-Catherine, depending on the clone (Table 4). However, if the general model had been used to calculate coarse root biomass of the same poplar plantations, coarse root biomass would have been overestimated by up to $18 \%$ on the high fertility sites, and underestimated by up to $25 \%$ on the moderate fertility sites (Table 4). Likewise, the estimated shoot to root ratio was also influenced by the modelling approach used to calculate coarse root biomass. Using the models developed for the two fertility classes, instead of the general model, resulted in a larger variation in the shoot to root ratio between the high and moderate fertility sites, with high fertility sites having higher shoot to root ratios than moderate fertility sites (Table 4).

\section{Relationship Between Shoot to Root Ratio and Environmental Variables}

Strong and highly significant relationships $(p<0.001)$ were observed between several proxies of soil fertility and shoot to root ratios calculated using coarse root biomass equations developed for the two soil fertility classes, with $R^{2}$ ranging

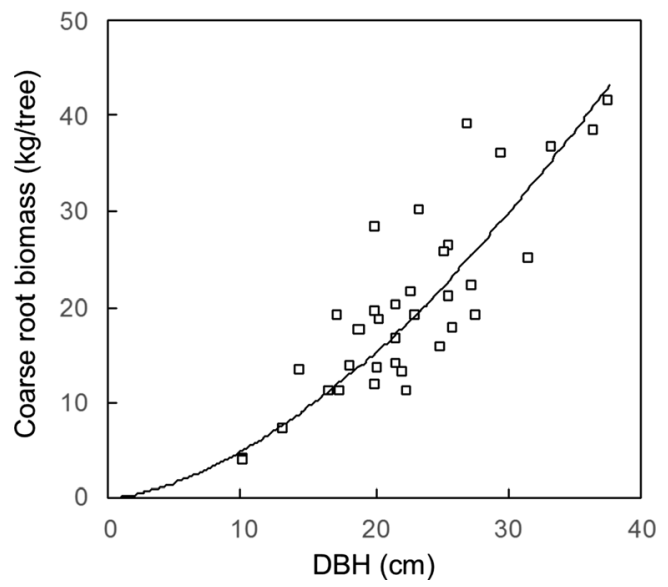

Fig. 2 General allometric relationship between diameter at breast height (DBH; in centimetres) and coarse root biomass (in kilogrammes per tree) in 13-year-old hybrid poplar plantations between 0.78 and 0.90 , depending on the variable (Fig. 5). These relationships suggest that the shoot to root ratio in poplar plantations is positively linked to soil $\mathrm{NO}_{3}$ supply rate, $\mathrm{Ca}$ supply rate, clay content and base saturation, but negatively linked to percent soil organic matter. Weaker positive relationships were also observed between soil $\mathrm{pH}$ and the shoot to root ratio $\left(R^{2}=0.56, p<0.01\right)$, and between soil CEC and the shoot to root ratio ( $R^{2}=0.34, p<0.05$; data not shown). Additionally, a strong negative relationship was observed between elevation, a proxy of growing season length in the region [46], and the shoot to root ratio of hybrid poplar plantations $\left(R^{2}=0.76\right.$, $p<0.001$; Fig. 5). Significant relationships were equally observed between environmental variables and the shoot to root ratio calculated using the general allometric relationship for coarse root biomass (Fig. 5). However, the rate at which environmental variables modulated this shoot to root ratio was lower, as was also the fit $\left(R^{2}\right)$ of these relationships.

\section{Discussion}

This study provides evidence that site fertility or quality influences the trajectory, or shape, of the allometric relationship between $\mathrm{DBH}$ and coarse root biomass of mature hybrid

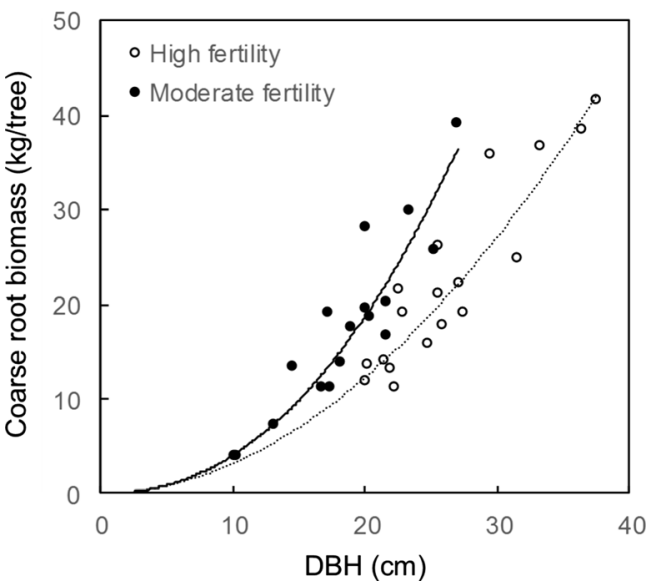

Fig. 3 Environment-specific allometric relationships between diameter at breast height (DBH; in centimetres) and coarse root biomass (in kilogrammes per tree) for two classes of soil fertility (high and moderate) in 13-year-old hybrid poplar plantations 


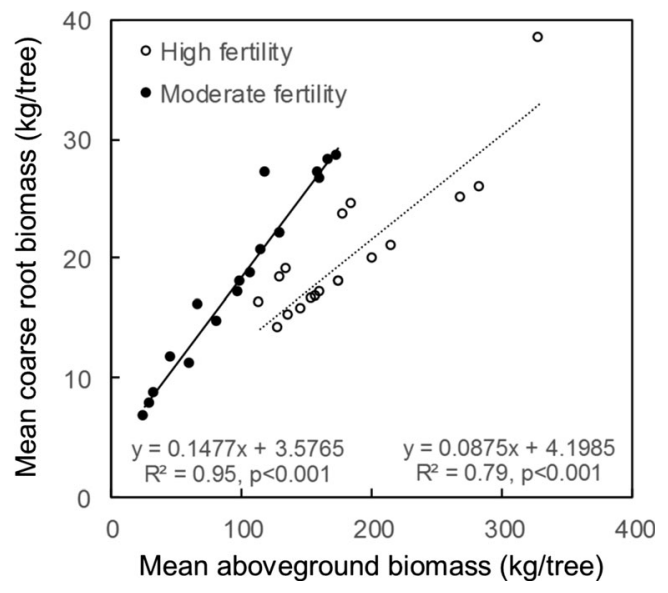

Fig. 4 Linear relationships between calculated mean aboveground woody biomass and mean coarse root biomass at the plot level for two classes of soil fertility (high and moderate) in 13-year-old hybrid poplar plantations. Mean aboveground biomass data are from Truax et al. [32]. For each relationship, $n=18$

poplar trees grown on abandoned fields (Fig. 3). This interpretation is supported by the ANCOVA results showing that site fertility class, as a main effect, and DBH, as a continuous covariate, were both highly significant $(p<0.001)$ in predicting coarse root biomass. In other words, coarse root biomass allocation in 13-year-old poplars is plastic, being both tree size and environment dependent. While the general allometric relationship between DBH and coarse root biomass was highly significant, with a relatively good fit $\left(R^{2}=0.78\right.$, $p<0.001$; Fig. 2, Table 3), both allometric relationships developed for the two site fertility classes (moderate and high), using the same data set, had a better fit $\left(R^{2}=0.90\right.$ and $0.81, p<0.001$; Fig. 3, Table 3). Consequently, environmentspecific equations describe more accurately the relationship between tree diameter growth and coarse root biomass growth in mature poplar plantations.

Our results support the "plastic allometry" hypothesis [45], but also the "optimal partitioning theory," which suggests that plants invest resources or allocate $\mathrm{C}$ to improve their access to the limiting factor [38]. A similar pattern of plastic allometry was equally found for shoot/root allometry in lodgepole pine stands along a fertility gradient [31]. In our specific case, exponentially higher root biomass was allocated for a given tree DBH in more nutrient poor environments, also located at higher elevation (Melbourne and Ste-Catherine sites; Tables 1 and 2, Fig. 3). The different slopes of the relationships between estimated mean aboveground biomass and mean coarse root biomass per tree also support the evidence of a flexible allometry (change in tree architecture) that optimises biomass allocation along a site fertility gradient (Fig. 4).

These results corroborate previous glasshouse experiments showing that a favourable $\mathrm{N}$ soil environment triggers changes in hybrid poplar tree architecture, which favours aboveground structures over the root system to increase $\mathrm{C}$ fixation capacity $[37,36]$. Evidence of plastic allocation patterns in response to resource availability have also been shown for seedlings of different tree species, including Betula pendula [67], Fagus sylvatica and, to a much lower extent, Picea abies [39]. Similar observations have been reported for herbaceous
Table 4 Site $\times$ clone interaction for aboveground woody biomass, coarse root biomass and the shoot to root ratio in 13-year-old hybrid poplar plantations

\begin{tabular}{|c|c|c|c|c|c|c|c|}
\hline \multirow[t]{2}{*}{ Sites } & \multirow[t]{2}{*}{ Clones } & \multirow[t]{2}{*}{$\begin{array}{l}\text { Aboveground } \\
\text { biomass (t/ha) }\end{array}$} & \multicolumn{2}{|c|}{$\begin{array}{l}\text { Coarse root } \\
\text { biomass (t/ha) }\end{array}$} & \multirow[t]{2}{*}{ Variation (\%) } & \multicolumn{2}{|c|}{ Shoot/root ratio } \\
\hline & & & General & Plastic & & General & Plastic \\
\hline \multirow[t]{3}{*}{ Bedford } & MxB-915311 & 117 & 14.6 & 12.4 & +18 & 8.0 & 9.4 \\
\hline & DNxM-915508 & 186 & 19.5 & 17.4 & +12 & 9.5 & 10.6 \\
\hline & DxN-3570 & 146 & 20.0 & 18.5 & +8 & 7.3 & 7.9 \\
\hline \multirow[t]{3}{*}{ Brompton } & MxB-915311 & 117 & 14.7 & 12.4 & +18 & 7.9 & 9.4 \\
\hline & DNxM-915508 & 119 & 14.1 & 12.1 & +17 & 8.4 & 9.8 \\
\hline & DxN-3570 & 94 & 15.4 & 13.2 & +16 & 6.1 & 7.1 \\
\hline \multirow[t]{3}{*}{ Melbourne } & MxB-915311 & 106 & 13.5 & 18.1 & -25 & 7.7 & 5.8 \\
\hline & DNxM-915508 & 85 & 11.0 & 14.3 & -23 & 7.6 & 5.9 \\
\hline & DxN-3570 & 22 & 4.5 & 5.2 & -13 & 4.6 & 4.1 \\
\hline \multirow[t]{5}{*}{ Ste-Catherine } & MxB-915311 & 71 & 10.5 & 12.6 & -17 & 6.6 & 5.6 \\
\hline & DNxM-915508 & 95 & 12.5 & 16.1 & -23 & 7.5 & 5.9 \\
\hline & DxN-3570 & 44 & 8.6 & 10.4 & -17 & 4.6 & 4.1 \\
\hline & SE & 14 & 1.6 & 2.2 & & 0.4 & 0.2 \\
\hline & $p<$ & 0.05 & 0.05 & 0.05 & & 0.01 & 0.05 \\
\hline
\end{tabular}

Coarse root biomass and the shoot to root ratio were calculated using a general allometric relationship, but also using the environment-specific relationships (plastic allometry) developed for the two site fertility classes. Data for aboveground woody biomass were taken from Truax et al. [32] 

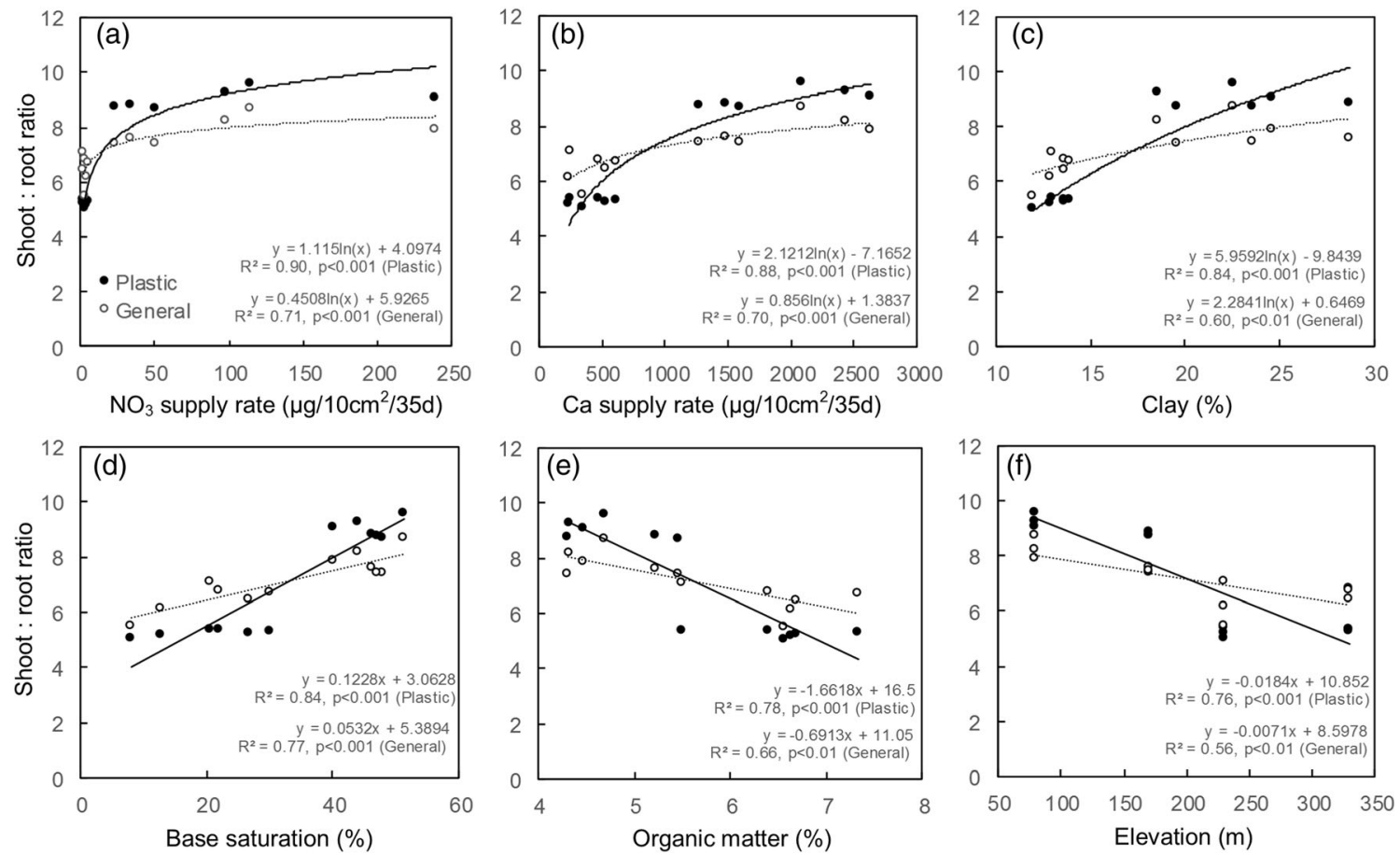

Fig. 5 Shoot to root ratio in hybrid poplar plantations as a function of a soil $\mathrm{NO}_{3}$ supply rate, $\mathbf{b}$ soil Ca supply rate, $\mathbf{c}$ soil clay content, $\mathbf{d}$ soil base saturation, e soil organic matter content and $\mathbf{f}$ site elevation. Shoot to root ratios were calculated using the general allometric relationship, but also

using the environment-specific relationships (plastic allometry) developed for the two soil fertility classes (See Table 4). Data were averaged at the block level for each relationship $(n=12)$

plants $[68,69]$ and for different tree species growing in forest environments $[31,70,71]$. In willow bioenergy crops, site fertility also causes changes in the relationship between stem diameter and aboveground biomass growth [28, 29]. Aboveground allometry was also likely affected by environmental conditions for a $\mathrm{T} \times \mathrm{M}$ hybrid growing in different locations of southern Scandinavia [30].

Being pioneer riparian species, the parental species of studied hybrid poplars (Aigeiros and Tacamahaca sections) often colonise nutrient poor mineral substrates such as sand or gravel bars along streams, but also sand dunes and beaches [72]. In these low fertility and well-drained soil habitats, newly established seedlings often have to grow under the additional stress of a low or rapidly declining water table [73]. The rapid development of root systems for resource acquisition, at the expense of shoot growth, is therefore critical to ensure seedling survival when resource availability is low or rapidly declining [74]. This adaptive strategy in response to riparian habitat features could explain the plasticity in root biomass allocation observed in this study. In many cases, tree ability to respond to limited resources by plasticity in allocation often declines with tree size and/or time of the exposure to the environmental stress $[40,39]$. However, this study provides evidence that a prolonged exposure (13 years) to different levels of soil fertility results in different allocation patterns to coarse root biomass (Tables 1 and 2, Figs. 3 and 4). Differences in elevation between moderate and high fertility sites could have also contributed to the plastic allometry pattern observed. Lower elevation sites benefit from a warmer climate in the region [46], and therefore higher soil temperature conditions, which may reduce the need to invest $\mathrm{C}$ in the root system because higher root ion uptake rates are generally observed at higher soil temperature [63].

To a certain extent, the interpretation that higher coarse root biomass allocation on lower fertility sites occurs to allow a higher nutrient uptake capacity is debatable. It is widely assumed that nutrient uptake is restricted to the narrow region of young fine roots located just behind the root tip [75]. Yet, recent evidence suggests that the majority of $\mathrm{N}$ uptake occurs in older woody roots of both coniferous and broadleaved seedlings [76]. Nitrogen uptake rate in older woody roots was found to be lower than in young fine roots, but the much higher total surface area of these woody roots provides the higher total $\mathrm{N}$ uptake [76]. Small woody roots also had important $\mathrm{P}$ and $\mathrm{K}$ uptake rates in 12-year-old slash pines growing under field conditions [77]. Additionally, despite the water uptake rate per surface area decline with woody root size, significant water uptake has been measured in spruce, beech and oak for woody roots of $4-5 \mathrm{~cm}$ in diameter [78]. Consequently, we cannot completely discard the idea that larger woody roots of poplars can contribute to nutrient uptake, although rates of nutrient or water uptake by coarse roots might be very low. The large surface area of coarse roots could be a determinant factor in nutrient absorption, especially on 
low fertility sites. Still, clear demonstration of the nutrient uptake capacity of larger woody roots of different tree species remains to be shown under field conditions.

On the other hand, the plastic allocation to coarse biomass observed in this study (Figs. 3 and 4) may be more linked to the storage function rather than the nutrient uptake function of coarse roots. As trees become more mature, internal remobilisation of stored $\mathrm{C}$ and $\mathrm{N}$ may become proportionally more important than uptake to fulfill nutritional requirements, because mature trees have larger storage pools and often slower uptake rates [79]. It is well-known that poplar coarse root biomass is an important storage site for non-structural carbohydrates, but also for amino acids in the form of bark storage proteins $[43,44]$. On lower fertility sites, it may be advantageous for poplars to allocate more belowground biomass to build a larger coarse root system for storage purposes. Stored carbohydrates and amino acids in roots could then be used locally, and in timely fashion, to sustain a higher level of fine root growth, symbiotic associations with fungi $[80,81]$ and root exudation $[82,83]$. These three processes have an increasing importance for nutrient capture as site fertility decreases [84-86]. This interpretation is consistent with the observations of Kobe et al. [87] made in seedlings of seven temperate tree species. These authors showed that total root mass, as a proportion of whole-plant mass, was higher in low vs. high soil $\mathrm{N}$ environment, with changes in root mass being mostly influenced by the increased storage of total nonstructural carbohydrates. The build-up of a larger pool of non-structural carbohydrates in roots could provide flexibility to temporal resource variations in soil environments [87], with such resource variations being typical of riparian habitats where parental species of the studied hybrid poplars naturally grow $[74,72]$. During periods when nutrients become scarce, non-structural carbohydrates stored in roots could be used to increase access to soil nutrients by providing an energy source for mycorrhizae and organic matter decomposers in the rhizosphere [87]. This energy source could then be used for the rapid production of fine roots and to support metabolic costs of nutrient uptake, as nutrients become more available [87]. In short, though our results are in accordance with the optimal partition theory, we cannot firmly conclude to which extent the plastic allocation to coarse root biomass is related to the nutrient uptake and/or the storage functions.

One outlier was removed from the data set of the Melbourne site (moderate fertility) because the coarse root biomass measured was disproportionally high for the DBH value $(\mathrm{DBH}=14.0 \mathrm{~cm}$, coarse root biomass $=20.7 \mathrm{~kg})$. Compared to the other plots of the Melbourne plantation, the plot where the outlier was observed had the lowest $\mathrm{NO}_{3}$ supply rate $\left(1 \mu \mathrm{g} / 10 \mathrm{~cm}^{2} / 35\right.$ days $)$, the lowest Ca supply rate (377 $\mu \mathrm{g} / 10 \mathrm{~cm}^{2} / 35$ days) and the lowest $\mathrm{pH}$ value (5.2). These low soil richness indicators and the presence of grey birch and willow seedlings in the plot understory were likely linked due to the poorer drainage conditions that were observed during root sampling of this outlier tree (J. Fortier, personal observation). Lower $\mathrm{pH}$, lower $\mathrm{N}$ mineralisation rate and soil decalcification/acidification are often observed in wetter soils [88]. Still, this outlier is in agreement with the idea that poplars allocate a higher proportion of biomass to coarse roots in low fertility environments. Consequently, much higher allocation to coarse root biomass than what is reported in this study may occur if hybrid poplars are grown on very low quality sites (ex: in acidic soils of clear-cut forest sites of the boreal shield ecoregion of Canada).

In this study, we have only sampled coarse root biomass located at a limited distance from the tree base, where most root biomass may be expected to provide a stability or anchorage function. This stability function may be especially important when plantation soil had been cultivated for site preparation prior to tree establishment, as was the case in this study. However, if the stability function of coarse root biomass would have been of overriding importance in the studied mature hybrid poplar trees, biomass allocation to coarse roots would have only been dependant of aboveground biomass allocation or DBH, regardless of site quality. Thus, our results contrast with those of Resh et al. [41] suggesting that only aboveground parameters of mature Eucalyptus need to be used to predict coarse root biomass, irrespective of fertilisation treatments or site quality. This result could be reflecting the high requirements for biomechanical stability in large Eucalyptus trees, or an indication of the nonplastic response of Eucalyptus coarse root biomass to nutritional environment.

Our results also challenge the notion that allometry of biomass allocation in plants is rarely affected by environmental features, with plant form or biomass allocation being generally the same at a given size independently of soil nutrient availability in the local environment [89, 90, 62]. Many studies have reported relationships between shoot to root ratio and environmental factors, but these relationships were often the sole consequence of allometric growth or apparent plasticity $[91,45]$. This is because shoot to root ratios generally increase as plant size increases, and plants are generally smaller and more "rooty" in harsher environments, but larger and more "shooty" in more favourable environments [45, 89, 92, 93]. As shown in Fig. 5, significant relationships were observed between environmental variables and shoot to root ratios calculated using the general allometric relationship for coarse root biomass (Fig. 2), but these were the consequence of allometric growth, not plasticity. However, when the shoot to root ratio was calculated using the environment-specific allometric relationships (Fig. 3), environmental factors had a more pronounced influence on the size of the shoot to root ratio because this ratio integrates both ontogeny and environmental effects (Fig. 5). Likewise, using the environment-specific relationships for coarse root biomass also yields much wider 
variations in the shoot to root ratio across plantation sites, compared to shoot to root ratios calculated using the general allometric relationship (Table 4).

In a meta-analysis on the root biomass of upland forests, Cairn et al. [17] found no relationship between shoot to root ratio and selected key environmental variables. In this study, shoot to root ratios of mature poplar plantations were strongly and positively correlated to several key indicators of soil fertility (Ca supply rate, clay content and base saturation; Fig. 5), with soil $\mathrm{NO}_{3}$ availability being the best predictor of the ratio $\left(R^{2}=0.90, p<0.001\right.$; Fig. 5$)$. This provides additional evidence that $\mathrm{N}$ availability in soils is a key factor driving biomass partitioning towards aboveground structures to increase or maintain $\mathrm{C}$ fixation capacity in hybrid poplars. Strong negative correlations between soil organic matter or elevation and shoot to root ratio were also observed (Fig. 5). This trend potentially reflects the co-variation between local climate and soil fertility (Tables 1 and 2) [64], with colder sites (higher elevation) generally being characterised by slower litter decomposition [94] and $\mathrm{N}$ mineralisation rates, higher soil organic matter content [95] and lower soil pH (Table 1), which could have favoured biomass allocation to roots.

Biomass estimates calculated with the environmentspecific relationships also suggest little variation of coarse root biomass in 13-year-old poplar plantations. With the exception of clone DxN-3570 that produced very low aboveground and coarse root biomass at the Melbourne site, coarse root biomass estimates had a similar range on moderate fertility sites (10.4-18.1 t/ha) and high fertility sites (12.1-18.5 t/ ha), despite aboveground woody biomass production showing much wider variations (Table 4). Greenhouse experiments also suggest that similar root biomass was observed between hybrid poplars growing under low and high $\mathrm{N}$ availability, with higher shoot biomass being observed when $\mathrm{N}$ was more available $[37,36]$. Our results are consistent with the analysis of Vicca et al. [85] who observed no differences in root biomass production between temperate forests growing on high and low fertility sites, despite aboveground wood production being three times higher in forests located on high soil fertility sites.

Finally, the results presented in this study have important implications for bioenergy crop models and C stock estimations because both rely on allometric equations developed for the different tree biomass compartments [16, 20, 21]. Being the largest biomass $\mathrm{C}$ pool after stems and branches, poplar coarse root biomass needs to be more accurately quantified [96]. Until now, only general allometric relationships had been developed for poplar coarse root biomass [24, 26, 22, 23, 19, $27,25]$, with no consideration for the potential effect of plantation environment on allometric trajectory. In this study, using the general allometric relationship developed across the four sites (Fig. 2, Table 3), instead of the environmentspecific relationships, would have resulted in a coarse root biomass overestimation of 8 to $18 \%$ on the high fertility sites (Bedford and Brompton), and an underestimation of 17 to $25 \%$ on the moderate fertility sites (Melbourne and SteCatherine; Table 4). Increasing the accuracy of coarse root biomass estimates is also important for a better understanding of $\mathrm{C}$ cycling in the soils. Large roots have particularly slow decay rates, and they can contribute to the belowground biomass C pool over a century after harvest [97], while having a short-term positive effect on soil organic $\mathrm{C}$ stocks once incorporated into the soil [98]. Lastly, more accurate coarse root biomass estimates are also be needed, as coarse root biomass may eventually represent a valuable bioenergy feedstock in some countries [19].

Acknowledgments We gratefully acknowledge funding received from Agriculture and Agri-Food Canada (Agricultural Greenhouse Gas Program) and the Ministère des Forêts, de la Faune et des Parcs du Québec ("Chantier sur la forêt feuillue" Program). We wish to thank Anne Déziel of the Berthierville MRNF nursery, who provided bare-root planting stocks. Our gratitude goes to regional forestry advisors André Goulet, Nicolas Meagher, Pierre Bellavance, Ken Dubé, Alain Paris and Marc Beaubien, as well as Daniel Lambert, for assistance with initial site selection. Thanks are also due to all of the owners of the plantation sites (Daniel Dubé, Carlo Iannuzzi, Jean Cloutier and Pierre Labrecque). We greatly appreciated the dedicated help of our field assistants (Joannie Lemelin, Annie Richard and Marc-Antoine Pétrin). A special thanks to Harry Isbrucker for providing us with a large amount of space for sample storage and preparation. A post-doctoral fellowship from the Fiducie de recherche sur la forêt des Cantons-de-l'Est (FRFCE) to Julien Fortier is gratefully acknowledged. Finally, we wish to thank the two anonymous reviewers for their positive comments and suggestions, which have contributed to improve this manuscript.

Compliance with Ethical Standards This research was funded by Agriculture and Agri-food Canada (Agricultural Greenhouse Gas Program) and by the Ministère des Forêts, de la Faune et des Parcs du Québec ("Chantier sur la forêt feuillue" Program).

Conflicts of Interest The authors declare that they have no conflict of interest.

Open Access This article is distributed under the terms of the Creative Commons Attribution 4.0 International License (http:// creativecommons.org/licenses/by/4.0/), which permits unrestricted use, distribution, and reproduction in any medium, provided you give appropriate credit to the original author(s) and the source, provide a link to the Creative Commons license, and indicate if changes were made.

\section{References}

1. FAO (2012) Improving lives with poplars and willows. Synthesis of Country Progress Reports. 24th Session of the International Poplar Commission, Dehradun, India, 30 Oct-2 Nov 2012. Working Paper IPC/12. Forest Assessment, Management and Conservation Division, FAO, Rome

2. Christersson L (2010) Wood production potential in poplar plantations in Sweden. Biomass Bioenergy 34(9):1289-1299

3. Nielsen UB, Madsen P, Hansen JK, Nord-Larsen T, Nielsen AT (2014) Production potential of 36 poplar clones grown at medium 
length rotation in Denmark. Biomass Bioenergy 64:99-109. doi:10. 1016/j.biombioe.2014.03.030

4. Werner C, Haas E, Grote R, Gauder M, Graeff-Hönninger S, Claupein W, Butterbach-Bahl K (2012) Biomass production potential from Populus short rotation systems in Romania. GCB Bioenergy 4(6):642-653. doi:10.1111/j.1757-1707.2012.01180.x

5. Arevalo CBM, Bhatti JS, Chang SX, Sidders D (2009) Ecosystem carbon stocks and distribution under different land-uses in north central Alberta, Canada. For Ecol Manag 257(8):1776-1785

6. Updegraff K, Baughman MJ, Taff SJ (2004) Environmental benefits of cropland conversion to hybrid poplar: economic and policy considerations. Biomass Bioenergy 27(5):411-428

7. Yemshanov D, McKenney D (2008) Fast-growing poplar plantations as a bioenergy supply source for Canada. Biomass Bioenergy 32(3):185-197

8. Rytter R-M (2012) The potential of willow and poplar plantations as carbon sinks in Sweden. Biomass Bioenergy 36:86-95. doi:10. 1016/j.biombioe.2011.10.012

9. Coleman MD, Isebrands JG, Tolsted DN, Tolbert VR (2004) Comparing soil carbon of short rotation poplar plantations with agricultural crops and woodlots in North Central United States. Environ Manag 33:299-308

10. Keith AM, Rowe RL, Parmar K, Perks MP, Mackie E, Dondini M, McNamara NP (2014) Implications of land-use change to short rotation forestry in Great Britain for soil and biomass carbon. GCB Bioenergy 2014:1-12. doi:10.1111/gcbb.12168

11. Walter K, Don A, Flessa H (2014) No general soil carbon sequestration under Central European short rotation coppices. GCB Bioenergy. doi:10.1111/gcbb.12177

12. Agostini F, Gregory A, Richter G (2015) Carbon sequestration by perennial energy crops: Is the jury still out? Bioenergy Res 1-24. doi:10.1007/s12155-014-9571-0

13. Zan CS, Fyles JW, Girouard P, Samson RA (2001) Carbon sequestration in perennial bioenergy, annual corn and uncultivated systems in southern Quebec. Agric Ecosyst Environ 86(2):135-144. doi:10. 1016/S0167-8809(00)00273-5

14. Pacaldo R, Volk T, Briggs R (2013) Greenhouse gas potentials of shrub willow biomass crops based on below- and aboveground biomass inventory along a 19-year chronosequence. Bioenergy Res 6(1):252-262. doi:10.1007/s12155-012-9250-y

15. Shorohova E, Ignatyeva O, Kapitsa E, Kauhanen H, Kuznetsov A, Vanha-Majamaa I (2012) Stump decomposition rates after clearfelling with and without prescribed burning in southern and northern boreal forests in Finland. For Ecol Manag 263:74-84. doi:10. 1016/j.foreco.2011.09.006

16. Brown S (2002) Measuring carbon in forests: current status and future challenges. Environ Pollut 116(3):363-372

17. Cairns M, Brown S, Helmer E, Baumgardner G (1997) Root biomass allocation in the world's upland forests. Oecologia 111:1-11

18. Alam A, Kellomäki S, Kilpeläinen A, Strandman H (2013) Effects of stump extraction on the carbon sequestration in Norway spruce forest ecosystems under varying thinning regimes with implications for fossil fuel substitution. GCB Bioenergy 5(4):445-458. doi:10. $1111 / \mathrm{gcbb} .12010$

19. Johansson T, Hjelm B (2012) Stump and root biomass of poplar stands. Forests 3(2):166-178

20. Surendran Nair S, Kang S, Zhang X, Miguez FE, Izaurralde RC, Post WM, Dietze MC, Lynd LR, Wullschleger SD (2012) Bioenergy crop models: descriptions, data requirements, and future challenges. GCB Bioenergy 4(6):620-633. doi:10.1111/j.17571707.2012.01166.x

21. Headlee W, Zalesny R Jr, Donner D, Hall R (2013) Using a processbased model (3-PG) to predict and map hybrid poplar biomass productivity in Minnesota and Wisconsin, USA. Bioenergy Res 6(1):196-210. doi:10.1007/s12155-012-9251-X
22. Fang S, Xue J, Tang L (2007) Biomass production and carbon sequestration potential in poplar plantations with different management patterns. J Environ Manag 85(3):672-679

23. Heilman PE, Ekuan G, Fogle D (1994) Above- and below-ground biomass and fine roots of 4 -year-old hybrids of Populus trichocarpa $\times$ Populus deltoides and parental species in shortrotation culture. Can J For Res 24(6):1186-1192

24. Ajit, Das DK, Chaturvedi OP, Jabeen N, Dhyani SK (2011) Predictive models for dry weight estimation of above and below ground biomass components of Populus deltoides in India: Development and comparative diagnosis. Biomass Bioenergy 35(3):1145-1152. doi:10.1016/j.biombioe.2010.12.001

25. McIvor IR, Douglas GB, Benavides R (2009) Coarse root growth of Veronese poplar trees varies with position on an erodible slope in New Zealand. Agrofor Syst 76(1):251-264. doi:10.1007/s10457009-9209-y

26. Brassard BW, Chen HYH, Bergeron Y, Paré D (2011) Coarse root biomass allometric equations for Abies balsamea, Picea mariana, Pinus banksiana, and Populus tremuloides in the boreal forest of Ontario, Canada. Biomass Bioenergy 35(10):4189-4196. doi:10. 1016/j.biombioe.2011.06.045

27. Ruark GA, Bockheim JG (1987) Below-ground biomass of 10-, 20-, and 32-year-old Populus tremuloides in Wisconsin. Pedobiologia 30:207-217

28. Mosseler A, Major JE, Labrecque M, Larocque GR (2014) Allometric relationships in coppice biomass production for two North American willows (Salix spp.) across three different sites. For Ecol Manag 320:190-196. doi:10.1016/j.foreco.2014.02.027

29. Verwijst T, Telenius B (1999) Biomass estimation procedures in short rotation forestry. For Ecol Manag 121(1-2):137-146. doi: 10.1016/S0378-1127(98)00562-3

30. Taeroe A, Nord-Larsen T, Stupak I, Raulund-Rasmussen K (2015) Allometric biomass, biomass expansion factor and wood density models for the OP42 hybrid poplar in southern Scandinavia. Bioenergy Res 1-12. doi:10.1007/s12155-015-9592-3

31. Pretzsch H, Uhl E, Biber P, Schütze G, Coates KD (2012) Change of allometry between coarse root and shoot of Lodgepole pine (Pinus contorta Dougl. ex. Loud.) along a stress gradient in the sub-boreal forest zone of British Columbia. Scand J For Res 27(6):532-544. doi:10.1080/02827581.2012.672583

32. Truax B, Gagnon D, Fortier J, Lambert F (2014) Biomass and volume yield in mature hybrid poplar plantations on temperate abandoned farmland. Forests 5(12):3107-3130

33. Block R, Van Rees K, Knight J (2006) A review of fine root dynamics in Populus plantations. Agrofor Syst 67(1):73-84

34. Broeckx LS, Verlinden MS, Berhongaray G, Zona D, Fichot R, Ceulemans R (2014) The effect of a dry spring on seasonal carbon allocation and vegetation dynamics in a poplar bioenergy plantation. GCB Bioenergy 6(5):473-487. doi:10.1111/gcbb.12087

35. Pregitzer KS, Zak DR, Curtis PS, Kubiske ME, Teeri JA, Vogel CS (1995) Atmospheric $\mathrm{CO}_{2}$, soil nitrogen and turnover of fine roots. New Phytol 129(4):579-585. doi:10.1111/j.1469-8137.1995. tb03025.x

36. Liu Z, Dickmann DI (1992) Responses of two hybrid Populus clones to flooding, drought, and nitrogen availability. I. Morphology and growth. Can J Bot 70(11):2265-2270. doi:10. 1139/b92-281

37. Cooke JEK, Timothy AM, Davis JM (2005) Shot-term physiological and developmental responses to nitrogen availability in hybrid poplar. New Phytol 167:41-52

38. Bloom AJ, Chapin FS III, Mooney HA (1985) Resource limitation in plants-an economic analogy. Annu Rev Ecol Syst 16:363-392. doi:10.2307/2097053

39. Schall P, Lödige C, Beck M, Ammer C (2012) Biomass allocation to roots and shoots is more sensitive to shade and drought in 
European beech than in Norway spruce seedlings. For Ecol Manag 266:246-253. doi:10.1016/j.foreco.2011.11.017

40. Niinemets Ü (2010) Responses of forest trees to single and multiple environmental stresses from seedlings to mature plants: past stress history, stress interactions, tolerance and acclimation. For Ecol Manag 260(10):1623-1639. doi:10.1016/j.foreco.2010.07.054

41. Resh S, Battaglia M, Worledge D, Ladiges S (2003) Coarse root biomass for eucalypt plantations in Tasmania, Australia: sources of variation and methods for assessment. Trees 17(5):389-399. doi: 10.1007/s00468-003-0250-6

42. Guo L, Chen J, Cui X, Fan B, Lin H (2013) Application of ground penetrating radar for coarse root detection and quantification: a review. Plant Soil 362(1-2):1-23. doi:10.1007/s11104-012-1455-5

43. Cooke JEK, Weih M (2005) Nitrogen storage and seasonal nitrogen cycling in Populus: bridging molecular physiology and ecophysiology. New Phytol 167(1):19-30. doi:10.1111/j.1469-8137.2005. 01451.x

44. Dietze MC, Sala A, Carbone MS, Czimczik CI, Mantooth JA, Richardson AD, Vargas R (2014) Nonstructural carbon in woody plants. Annu Rev Plant Biol 65(1):667-687. doi:10.1146/annurevarplant-050213-040054

45. Weiner J (2004) Allocation, plasticity and allometry in plants. Perspect Plant Ecol Evol Syst 6(4):207-215. doi:10.1078/14338319-00083

46. Robitaille A, Saucier J-P (1998) Paysages régionaux du Québec méridional. Les publications du Québec, Ste-Foy

47. Périnet P, Gagnon H, Morin S (2010) Liste des clones recommandés de peuplier hybride par sous-région écologique au Québec (mise à jour octobre 2010). Direction de la recherche forestière, MRN, Québec

48. Conseil des productions végétales du Québec (1988) Méthodes d'analyse des sols, des fumiers et des tissus végétaux. AGDEX 533, Québec

49. Bouyoucos GJ (1962) Hydrometer method improved for making particle size analysis of soils. Agron J 54:464-465

50. CRAAQ (2003) Guide de référence en fertilisation, 1re édition. Centre de référence en agriculture et agroalimentaire du Québec, Ste-Foy

51. Tran TS, Simard RR (1993) Mehlich III-Extractable elements. In: Carter MR (ed) Soil sampling and methods of analysis. Canadian Society of Soil Science. Lewis Publishers, Boca Raton, pp 43-49

52. AOAC (1999) Association of Official Analytical Chemists official methods. Method 984.27: calcium, copper, iron, magnesium, manganese, phosphorus, potassium, sodium and zinc in infant formulainductively coupled plasma emission spectroscopic. 16th edition edn. AOAC International Rockville (MD), USA

53. Qian P, Schoenau JJ, Huang WZ (1992) Use of Ion exchange membranes in routine soil testing. Commun Soil Sci Plant Anal 23(15): 1791-1804

54. Fortier J, Truax B, Gagnon D, Lambert F (2013) Mature hybrid poplar riparian buffers along farm streams produce high yields in response to soil fertility assessed using three methods. Sustainability 5(5):1893-1916

55. Fortier J, Truax B, Lambert F, Gagnon D, Chevrier N (2012) Clonespecific response in leaf nitrate reductase activity among unrelated hybrid poplars in relation to soil nitrate availability. Int J For Res 2012:1-10. doi:10.1155/2012/103878

56. Taylor BN, Beidler KV, Cooper ER, Strand AE, Pritchard SG (2013) Sampling volume in root studies: the pitfalls of undersampling exposed using accumulation curves. Ecol Lett 16(7): 862-869. doi:10.1111/ele.12119

57. Ferro A, Chard J, Kjelgren R, Chard B, Turner D, Montague T (2001) Groundwater capture using hybrid poplar trees: evaluation of a system in Ogden, Utah. Int J Phytoremediation 3(1):87-104. doi:10.1080/15226510108500051
58. Faulkner HG (1976) Root distribution, amount and development from 5-year-old Populus $\times$ euroamericana (Dode) Gunier. M.Sc. Thesis, University of Toronto, Toronto, ON, Canada

59. West P (2009) Tree and forest measurement. Springer-Verlag, Berlin Heidelberg

60. Picard N, Saint-André L, Henry M (2012) Manual for building tree volume and biomass allometric equations: from field measurement to prediction. Food and Agricultural, Organization of the United Nations, Rome, and Centre de Coopération Internationale en Recherche Agronomique pour le Développement, Montpellier

61. Royston P (1982) An extension of Shapiro and Wilk's W test for normality to large samples. Appl Stat 31(2):115-124

62. Niklas KJ (2004) Plant allometry: is there a grand unifying theory? Biol Rev 79(04):871-889. doi:10.1017/S1464793104006499

63. Pregitzer KS, King JS, Burton AJ, Brown SE (2000) Responses of tree fine roots to temperature. New Phytol 147(1):105-115. doi:10. 1046/j.1469-8137.2000.00689.x

64. Truax B, Gagnon D, Fortier J, Lambert F (2012) Yield in 8 year-old hybrid poplar plantations on abandoned farmland along climatic and soil fertility gradients. For Ecol Manag 267(1):228-239

65. Chojnacky DC, Heath LS, Jenkins JC (2014) Updated generalized biomass equations for North American tree species. Forestry 87(1): 129-151. doi:10.1093/forestry/cpt053

66. Ter-Mikaelian MT, Korzukhin MD (1997) Biomass equations for sixty-five North American tree species. For Ecol Manag 97(1):1-24

67. Ericsson T (1995) Growth and shoot: root ratio of seedlings in relation to nutrient availability. Plant Soil 168-169(1):205-214. doi:10.1007/BF00029330

68. Shipley B, Meziane D (2002) The balanced-growth hypothesis and the allometry of leaf and root biomass allocation. Funct Ecol 16(3): 326-331. doi:10.1046/j.1365-2435.2002.00626.x

69. Gedroc JJ, McConnaughay KDM, Coleman JS (1996) Plasticity in root/shoot partitioning: optimal, ontogenetic, or both? Funct Ecol 10(1):44-50. doi:10.2307/2390260

70. Lines ER, Zavala MA, Purves DW, Coomes DA (2012) Predictable changes in aboveground allometry of trees along gradients of temperature, aridity and competition. Glob Ecol Biogeogr 21(10): 1017-1028. doi:10.1111/j.1466-8238.2011.00746.x

71. Bonser SP, Aarssen LW (1994) Plastic allometry in young sugar maple (Acer saccharum): adaptive responses to light Availability. Am J Bot 81(4):400-406. doi:10.2307/2445488

72. Dickmann DI, Kuzovkina YA (2008) Poplars and willows of the world, with emphasis on silviculturally important species. FAO Forest Management Division Working Paper IPC/9-2, Rome

73. Kranjcec J, Mahoney JM, Rood SB (1998) The responses of three riparian cottonwood species to water table decline. For Ecol Manag 110(1-3):77-87. doi:10.1016/S0378-1127(98)00276-X

74. Mahoney JM, Rood SB (1991) A device for studying the influence of declining water table on poplar growth and survival. Tree Physiol 8(3):305-314. doi:10.1093/treephys/8.3.305

75. Näsholm T (2014) Old roots contribute to nitrogen uptake by tree seedlings. Tree Physiol 34(4):331-333. doi:10.1093/treephys/ tpu024

76. Hawkins BJ, Robbins S, Porter RB (2014) Nitrogen uptake over entire root systems of tree seedlings. Tree Physiol 34(4):334-342. doi:10.1093/treephys/tpu005

77. Escamilla JA, Comerford NB (2000) Phosphorus and potassium uptake by woody roots of twelve-year-old slash pine trees. For Ecol Manag 129(1-3):153-166. doi:10.1016/S0378-1127(99) 00149-8

78. Lindenmair J, Matzner E, Zimmermann R (2004) The role of woody roots in water uptake of mature spruce, beech, and oak trees. In: Matzner E (ed) Biogeochemistry of Forested Catchments in a Changing Environment. Ecological Studies, vol 172. Springer, Berlin, pp 279-289. doi:10.1007/978-3-662-06073-5_17 
79. Millard P, Grelet G-A (2010) Nitrogen storage and remobilization by trees: ecophysiological relevance in a changing world. Tree Physiol 30(9):1083-1095. doi:10.1093/treephys/tpq042

80. Gherghel F, Behringer D, Haubrich S, Schlauß M, Fey-Wagner C, Rexer K-H, Janßen A, Kost G (2014) Former land use and host genotype influence the mycorrhizal colonization of poplar roots. Forests 5(12):2980-2995

81. Khasa PD, Chakravarty P, Robertson A, Thomas BR, Dancik BP (2002) The mycorrhizal status of selected poplar clones introduced in Alberta. Biomass Bioenergy 22(2):99-104. doi:10.1016/S09619534(01)00072-1

82. Jordahl JL, Foster L, Schnoor JL, Alvarez PJJ (1997) Effect of hybrid poplar trees on microbial populations important to hazardous waste bioremediation. Environ Toxicol Chem 16(6):13181321

83. Smith WH (1976) Character and significance of forest tree root exudates. Ecology 57(2):324-331. doi:10.2307/1934820

84. Keyes MR, Grier CC (1981) Above- and below-ground net production in 40-year-old Douglas-fir stands on low and high productivity sites. Can J For Res 11(3):599-605. doi:10.1139/x81-082

85. Vicca S, Luyssaert S, Peñuelas J, Campioli M, Chapin FS, Ciais P, Heinemeyer A, Högberg P, Kutsch WL, Law BE, Malhi Y, Papale D, Piao SL, Reichstein M, Schulze ED, Janssens IA (2012) Fertile forests produce biomass more efficiently. Ecol Lett 15(6):520-526. doi:10.1111/j.1461-0248.2012.01775.x

86. Yin H, Li Y, Xiao J, Xu Z, Cheng X, Liu Q (2013) Enhanced root exudation stimulates soil nitrogen transformations in a subalpine coniferous forest under experimental warming. Glob Chang Biol 19(7):2158-2167. doi:10.1111/gcb.12161

87. Kobe RK, Iyer M, Walters MB (2010) Optimal partitioning theory revisited: nonstructural carbohydrates dominate root mass responses to nitrogen. Ecology 91(1):166-179. doi:10.1890/090027.1

88. Schaetzl RJ, Anderson S (2005) Soils: Genesis and geomorphology. Cambridge University Press, Cambridge

89. Müller I, Schmid B, Weiner J (2000) The effect of nutrient availability on biomass allocation patterns in 27 species of herbaceous plants. Perspect Plant Ecol Evol Syst 3(2):115-127. doi:10.1078/ 1433-8319-00007
90. Enquist BJ, Niklas KJ (2002) Global allocation rules for patterns of biomass partitioning in seed plants. Science 295(5559):1517-1520. doi:10.1126/science. 1066360

91. McConnaughay KDM, Coleman JS (1999) Biomass allocation in plants: ontogeny or optimality? A test along three resource gradients. Ecology 80(8):2581-2593. doi:10.1890/0012-9658(1999) 080[2581:BAIPOO]2.0.CO;2

92. Cahill JF (2003) Lack of relationship between below-ground competition and allocation to roots in 10 grassland species. J Ecol 91(4): 532-540. doi:10.1046/j.1365-2745.2003.00792.x

93. Cogliastro A, Gagnon D, Bouchard A (1993) Effet des sites et des traitements sylvicoles sur la croissance, l'allocation en biomasse et l'utilisation de l'azote de semis de quatre espèces feuillues en plantations dans le sud-ouest du Québec. Can J For Res 23(2):199-209. doi:10.1139/x93-027

94. Trofymow JA, Moore TR, Titus B, Prescott C, Morrison I, Siltanen M, Smith S, Fyles J, Wein R, Camiré C, Duschene L, Kozak L, Kranabetter M, Visser S (2002) Rates of litter decomposition over 6 years in Canadian forests: influence of litter quality and climate. Can J For Res 32(5):789-804. doi:10.1139/x01-117

95. Kirschbaum MUF (1995) The temperature dependence of soil organic matter decomposition, and the effect of global warming on soil organic C storage. Soil Biol Biogeochem 27(6):753-760. doi: 10.1016/0038-0717(94)00242-S

96. Fortier J, Truax B, Gagnon D, Lambert F (2015) Biomass carbon, nitrogen and phosphorus stocks in hybrid poplar buffers, herbaceous buffers and natural woodlots in the riparian zone on agricultural land. J Environ Manag 154:333-345. doi:10.1016/j.jenvman. 2015.02.039

97. Liski J, Kaasalainen S, Raumonen P, Akujärvi A, Krooks A, Repo A, Kaasalainen M (2014) Indirect emissions of forest bioenergy: detailed modeling of stump-root systems. GCB Bioenergy 6(6): 777-784. doi:10.1111/gcbb.12091

98. Toenshoff C, Stuelpnagel R, Joergensen R, Wachendorf C (2013) Carbon in plant biomass and soils of poplar and willow plantations - implications for SOC distribution in different soil fractions after re-conversion to arable land. Plant Soil 367(1-2):407-417. doi:10.1007/s11104-012-1481-3 